\title{
THE EFFECT OF AIR VELOCITY ON THE CHARACTERISTICS PRODUCED BY CONVENTIONAL DRYING OF Tectona grandis L.f. WOOD
}

\author{
Florencio Teodoro Trujillo ${ }^{1 *}$, Ricardo Jorge Klitzke ${ }^{2}$, Márcio Pereira Da Rocha ${ }^{3}$, \\ Héctor E. Gonzales Mora ${ }^{4} \&$ Carlos E. Chuquicaja Segura ${ }^{5}$ \\ ${ }^{1 *}$ Faculty of Forestry Sciences of the National Agrarian University - La Molina (UNALM), Lima, Peru - ftrujillo@ lamolina.edu.pe
${ }^{2}$ Postgraduate Program in Forestry Science at the Federal University of Paraná, Brazil - rjkklitzke@ gmail.com
${ }^{3}$ Postgraduate Program in Forestry Science at the Federal University of Paraná, Brazil - mprocha01@ gmail.com
${ }^{4}$ Faculty of Forestry Sciences of the National Agrarian University - La Molina (UNALM), Lima, Peru - egonzales@lamolina.edu.pe
${ }^{5}$ Faculty of Forestry Sciences of the National Agrarian University - La Molina (UNALM), Lima, Peru - cchsegura@lamolina.edu.pe
}

Received for publication: 15/08/2020 - Accepted for publication on 11/01/2021

\begin{abstract}
Resumo
Efeito da velocidade do ar nas características da secagem convencional da madeira de Tectona grandis l.f. $\mathrm{O}$ efeito da velocidade do ar de 2,5 e 3,5 $\mathrm{ms}^{-1}$ foi avaliado na secagem artificial de oito cargas de 60 placas cada, de duas posições de altura do poço: base e topo, com umidade inicial em verde e no PSF por secagem ao ar, usando vinte árvores de Tectona grandis Lf de uma plantação de 33 anos em Chanchamayo, Peru. Determinou-se o tempo, a taxa e a qualidade de secagem da madeira. Na secagem ao ar, a correlação de Pearson foi linear positiva entre a taxa de secagem de água livre com temperatura $(0,997)$ e velocidade do ar $(0,987)$, e linear negativa com umidade relativa do ar $(-0,996)$, precipitação $(-0,97)$ e tempo de secagem $(-0,976)$. O tempo de secagem artificial da madeira apresentou relação direta significativa com o nível de umidade inicial e inversa com a velocidade do ar. A taxa de secagem da água livre mostrou uma relação direta significativa com a velocidade do ar e foi significativamente maior do que a da água higroscópica. A posição da madeira na altura do poço não influenciou significativamente o tempo e a taxa de ar e secagem artificial. A qualidade de secagem da madeira não apresentou dependência significativa da velocidade do ar, da posição da madeira na altura do poço ou da umidade inicial de secagem. Os defeitos da secagem observados não comprometem a produção de produtos de qualidade com teor de umidade final uniforme de $10 \%$.

Palavras-chave: secagem artificial, velocidade do ar, teca.
\end{abstract}

\begin{abstract}
The effect of air velocity of 2.5 and $3.5 \mathrm{~ms}^{-1}$ was evaluated in the artificial drying of eight loads of 60 boards each, at two height positions of the shaft: the base and the top, with initial humidity in green and in the PSF by air drying, using twenty Tectona grandis Lf trees from a 33-year-old plantation in Chanchamayo, Peru. The drying time, rate, and quality of the wood were determined. In air drying, the Pearson correlation was positive linear between the free water drying rate with temperature (0.997) and air velocity $(0.987)$, and negative linear with relative air humidity (-0.996), precipitation (-0.97), and drying time (-0.976). The artificial drying time of the wood showed a significant direct relationship with the initial humidity level, and an inverse relationship with the air velocity. The drying rate of free water showed a significant direct relationship with the air velocity, while it was significantly higher than that of hygroscopic water. The position of the wood at the height of the shaft did not significantly influence the time and rate of both air and artificial drying. The quality of the wood drying did not show significant dependence on the air velocity, the position of the wood at the height of the shaft, and on the initial drying humidity. The drying defects observed do not compromise the production of quality products with a uniform final moisture content of $10 \%$.

Keywords: conventional drying, air velocity, teak.
\end{abstract}

\section{INTRODUCTION}

The conventional drying time of a load of wood depends on the initial moisture content, final moisture content and heartwood content, as well as on the temperature, relative humidity and air velocity. The relationship of the combination of these factors and the drying time are important for an efficient operation of the drying process (JUNAC, 1989; CONNERS, 2012). In this regard, Denig et al. (2000) state that the search for greater drying efficiency almost always means a reduction in time. The main factors that condition efficiency are related to the preparation of the wood, the desired quality, the type of kiln and the control of the drying process. The significant effect of air velocity on the drying speed and time was determined by Santini and Haselein (2002) using Pinus elliottii wood; the results showed a direct proportional relationship of drying rate with air velocity and wood moisture. When drying Norway spruce wood (Picea abies L. Karst.) with variable air velocity, Steiner et al. (2011) determined that too early and/or too strong reduction result in reduced drying speed and large variations in moisture content. For this reason, it is advisable to gradually reduce the air velocity from $40 \%$ to $20 \%$ moisture content. 
This was corroborated by Majka (2012) when drying oak wood (Quercus sp.), he observed that excessive reduction of the fan speed below the level that guarantees drying conditions and uniformity of air flow, increases the differences in drying conditions of stacked wood and negatively influences the drying quality of the stack. Wallace and Avramidis (2016), when studying the impact of airflow on the drying quality of western hemloc (Tsuga heterophylla [Raf] Sarg.) and Amabilis fir (Abies amabilis [Doug.] Forbes) species with basic densities of 0.43 and $0.4 \mathrm{~g} \mathrm{~cm}^{-3}$ respectively from British Columbia, Canada, confirmed that there are advantages to using a variable speed drive to control fan velocity during the later stages of the drying process, where no statistical differences were found in product quality at the end of the drying. In this regard, Vigberg et al. (2015), when estimating the effect of the fan velocity on airflow distribution during the drying of $50 \mathrm{~mm}$ thick pine (Pinus sylvestris) in an industrial kiln in Sweden, determined that airflow distribution did not change significantly as fan speed was reduced, and positions where air movement was stopped were not found.

Regarding the behavior of teak wood when submitted to artificial drying, Betancur et al. (2000), when drying 9-year-old wood from $110 \%$ to $12 \%$ with the JUNAC drying programs of the moderate, strong, and soft type, determined drying times of 96, 110, and 127 hours respectively, and observed the presence of collapse and superficial hardening with the moderate and strong programs. In turn, Berrocal et al. (2017), when evaluating 11year-old wood in artificial drying, determined that the drying rate decreased from $20 \%$ to $8 \%$ per day with moisture contents of $80 \%$ and $40 \%$ respectively, while managing to obtain low incidence of drying defects.

On the other hand, Loiola et al. (2015) dried 25-mm thick teak wood in a solar drying kiln, taking it in 98 days from a $115.4 \%$ to a $11.5 \%$ moisture content, with an average drying rate of $0.95 \%$ and $0.51 \%$ per day of free water and hygroscopic water respectively; the teak wood did not develop drying stress. Regarding the characteristics of teak wood in air drying, Braz et al. (2015) evaluated 3-cm-thick, 15-year-old wood, observing that in a period of 89 days, the moisture content of $70.9 \%$ reached $11.4 \%$ with a drying rate of $3 \%$ and $0.3 \%$ per day of free water and hygroscopic water respectively, with low incidence of drying defects.

According to Bounduelle et al. (2015), when evaluating the physical properties of 18-year-old teak wood, it was determined that it has good dimensional stability, and that it can be used for lamination, wood siding, doors, decoration and furniture applications. In this regard, Cremonez et al (2015), when evaluating the influence of the age of 10, 13 and 17-year-old wood on the specific gravity and Janka hardness for use in flooring, determined that with age, the gravity and hardness showed an increasing trend with a good degree of correlation, with results close to species traditionally used for the production of flooring and household products.

This study was based on the following hypotheses: a) Air velocity significantly influences when the drying time is shorter, b) Air velocity significantly influences the increase of the drying rate or speed, and c) The drying quality of teak wood depends on the drying speed. Therefore, the effect of air velocity on the conventional drying characteristics of teak wood (Tectona grandis L. f.) of two levels of tree height and with two levels of initial drying moisture content is evaluated. The results will allow for better processing of teak wood in the country.

\section{MATERIAL \& METHODS}

\section{Location of the Experimental Plantation}

Twenty 33-year-old (1985-2018) trees were selected from the experimental plantation of 5.8 hectares of teak wood (Tectona grandis L.f.), from the Fundo Genova of the National Agrarian University - La Molina (UNALM), located in the province of Chanchamayo, department of Junín, Peru $\left(11^{\circ} 07^{\prime} 01^{\prime \prime} \mathrm{S}\right.$ and $\left.75^{\circ} 20^{\prime} 01^{\prime \prime} \mathrm{W}\right)$, at an average altitude of 751 meters above sea level.

\section{Experimental Planning of the Study}

Eight wood loads, four with initial green wood moisture (H1) and four with air-drying up to the average moisture content near the fiber saturation point (PSF) (H2) were artificially dried, in order to evaluate the influence on drying time and the presence of collapse in the wood loads with (H1) (DENIG et al., 2000). In each group of four loads, two loads came from the average height of the shaft $(3.5 \mathrm{~m})$ to the bottom or base (B) and the other two from the average height to the upper part or top (T), evaluating the effect of the longitudinal position of the wood on drying time and quality (MIRANDA et al., 2011; BOUNDUELLE et al., 2015). Finally, in each group of two loads with equal initial moisture content ( $\mathrm{H} 1$ and $\mathrm{H} 2)$ and position in the tree (B and T), an air velocity of $2.5 \mathrm{~m} \mathrm{~s}^{-1}$ (V1) was used with one load of wood and $3.5 \mathrm{~m} \mathrm{~s}^{-1}$ (V2) with the other, evaluating its effect on drying time, rate and quality, at a final moisture content of $10 \%$. For the air velocities, the studies of Betancur et al. (2000), Aquino et al. (2010), and Berrocal et al. (2017) were taken into account. According to the schedule described in Table 1, on each date, five trees were extracted and two $3 \mathrm{~m}$ long logs were obtained from each one. 
Table 1: Schedule for the Harvesting, Sawing, Air Drying and Conventional Drying of Teak Wood Tabela 1: Cronograma de colheita e serragem de madeira de teca, secagem ao ar e convencional

\begin{tabular}{c|c|c|c|c|c|c|c}
\hline $\begin{array}{c}\text { Wood } \\
\text { Loading }\end{array}$ & $\begin{array}{c}\text { Harvest } \\
(\text { days/month) }\end{array}$ & $\begin{array}{c}\text { Air Drying } \\
(\text { days/month })\end{array}$ & $\begin{array}{c}\text { Artificial Drying } \\
(\text { days /month })\end{array}$ & $\begin{array}{c}\text { Air Velocity } \\
\left(\mathrm{m} \mathrm{s}^{-1}\right)\end{array}$ & $\begin{array}{c}\text { Tree Height } \\
(\mathrm{m})\end{array}$ & $\begin{array}{c}\text { Initial Moisture } \\
\text { Content }(\%)\end{array}$ & $\begin{array}{c}\text { Boards } \\
(\text { No. })\end{array}$ \\
\hline 1 & \multirow{2}{*}{$21-24 / 4$} & --- & $27 / 4-06 / 5$ & $2,5(\mathrm{~V} 1)$ & Base (B) & Green (H1) & 60 \\
3 & $27 / 4-13 / 5$ & $16-22 / 5$ & $2,5(\mathrm{~V} 1)$ & Top (T) & PSF (H2) & 60 \\
\hline 2 & \multirow{2}{*}{$02-04 / 5$} & --- & $9-16 / 5$ & $3,5(\mathrm{~V} 2)$ & Top (T) & Green (H1) & 60 \\
5 & & $11 / 5-04 / 6$ & $4-10 / 6$ & $3,5(\mathrm{~V} 2)$ & Base (B) & PSF (H2) & 60 \\
\hline 4 & \multirow{2}{*}{$20-22 / 5$} & --- & $26 / 5-01 / 6$ & $3,5(\mathrm{~V} 2)$ & Base (B) & Green (H1) & 60 \\
7 & & $28 / 5-14 / 7$ & $18-23 / 7$ & $3,5(\mathrm{~V} 2)$ & Top (T) & PSF (H2) & 60 \\
\hline 6 & \multirow{2}{*}{$07-08 / 6$} & --- & $13-21 / 6$ & $2,5(\mathrm{~V} 1)$ & Top (T) & Green (H1) & 60 \\
8 & & $15 / 6-01 / 8$ & $01-07 / 8$ & $2,5(\mathrm{~V} 1)$ & Base (B) & PSF (H2) & 60 \\
\hline
\end{tabular}

Wood Load \& Drying Control Characteristics

The dimensions of the wood load for air and artificial drying were: 500x1000x1000 mm (height $\mathrm{x}$ width $\mathrm{x}$ length), consisting of $6025 \times 150 \times 1000 \mathrm{~mm}$ boards (thickness $\mathrm{x}$ width $\mathrm{x}$ length), with the ends sealed with liquid wax, arranged in 10 lines with a volume of approximately $0.25 \mathrm{~m}^{3}$ and with $25 \times 25 \times 1000 \mathrm{~mm}$ spacers (thickness $\mathrm{x}$ width $\mathrm{x}$ length) arranged in four columns along the stack, and ten lines of spacers at the top, as indicated by JUNAC (1989). To control the process, five slabs were selected from each load, obtaining the 30-cm-long drying control specimen from the center, and for the initial moisture content, two 25-mm-long specimens from the area adjacent to the ends of the drying control specimen were selected, using the following equations (DENIG et al., 2000):

$$
\% \mathrm{CHI}=\left(\frac{\mathrm{Mh}-\mathrm{Ma}}{\mathrm{Ma}}\right) \times 100 ; \quad \mathrm{Ma}=\frac{\mathrm{Mh} * 100}{100+\% \mathrm{CH}}
$$

Where: $\mathrm{CHI}=$ Initial Moisture Content $(\%) ; \mathrm{Mh}=$ Moist Mass of the Sample $(\mathrm{g})$

$\mathrm{Ma}=$ Anhydrous Sample Mass at 0\% (g); $\mathrm{CH}=$ Sample Moisture Content (\%)

Open Air pre-drying of the Wood

Open air drying was carried out in the yard of the Faculty of Forestry Sciences of the National Agrarian University - La Molina; the 45-cm-high base of the horizontal stack (JUNAC; 1989) was provided with six 23 cm-high piles from the ground, two cross beams of 130x75x1000 mm (thickness $\mathrm{x}$ width $\mathrm{x}$ length) and four crossbeams of $100 \times 75 \times 1000$ mm (thickness x width x length). Drying control was performed by weighing five samples to an average value close to the PSF (BRAZ et al., 2015). A roof prevented the incidence of solar rays and precipitation; the meteorological variables of the air-drying period shown in Table 2 are comprised in the autumn (March 19 to June 19) and winter (June 20 to September 21) seasons.

Table 2: Meteorological Variables in Air Drying of 33-year-old Tectona grandis Wood from Peru Tabela 2: Variáveis meteorológicas na secagem ao ar da madeira Tectona grandis de 33 anos do Peru

\begin{tabular}{|c|c|c|c|c|c|c|c|}
\hline \multirow{2}{*}{$\begin{array}{c}\text { Wood } \\
\text { Load } \\
(\#)\end{array}$} & \multicolumn{7}{|c|}{ Average Weather in Air-dry Time } \\
\hline & $\begin{array}{c}\text { Time } \\
\text { (days/month) }\end{array}$ & Season & Days & $\begin{array}{c}\text { Temperature } \\
\left({ }^{\circ} \mathrm{C}\right) \\
\end{array}$ & $\begin{array}{l}\text { Precipitation } \\
(\mathrm{mm} / \mathrm{h})\end{array}$ & $\begin{array}{c}\text { Relative Moisture } \\
\text { Content }(\%)\end{array}$ & $\begin{array}{c}\text { Air Velocity } \\
(\mathrm{m} / \mathrm{s})\end{array}$ \\
\hline (3) & $27 / 4-13 / 5$ & Autumn & 15,5 & 20,0 & 0,0005 & 76,4 & 3,1 \\
\hline (5) & $11 / 5-04 / 6$ & Autumn & 23,8 & 17,7 & 0,0030 & 80,5 & 2,9 \\
\hline (7) & $28 / 5-14 / 7$ & Autumn/Winter & 47,1 & 15,9 & 0,0078 & 85,0 & 2,5 \\
\hline (8) & $15 / 6-01 / 8$ & Autumn/Winter & 46,8 & 15,7 & 0,0089 & 84,8 & 2,6 \\
\hline
\end{tabular}

SOURCE: SENAMHI Weather Station Von Humboldt Station at the National Agrarian University - La Molina (2020).

\section{Conventional Drying Process}

The 1.2- $\mathrm{m}^{3}$ chamber was provided with two 0.5-Hp axial fans. Control of the air velocities was carried out using the portable anemometer TROTEC BA16 in the wood load (JUNAC; 1989). The heat source was made up of two 3500-W resistors, while the relative humidity was regulated by two ventilators and two water sprinklers (a 0.5-hp pump and a 1100-lt. tank). The temperature, the equilibrium humidity (EMC), and the wood humidity (MC) were controlled using the MC 2000 (NIGOS). 
Table 3 shows the climatic variables of the drying stages; the initial conditioning shows a level for heating the wood (JUNAC, 1989; CONNERS, 2012), as well as a level to prepare the wood to the conditions of the drying program based on the experience of Betancurt et al. (2000).

The actual drying was carried out with the JUNAC (1989) moderate drying program up to an average moisture content of $10 \%$. Moisture equalization of the wood was carried out on the basis of the control sample with the highest moisture content up to a final moisture content of $10 \%$. The final conditioning was carried out for a period of 24 hours. The drying process was carried out by controlling the weight of five samples every 8 hours up to an average final moisture content of 10\%, based on JUNAC (1989); Denig et al. (2000), and Conners (2012).

Table 3: Climatic Variables of the Artificial Drying Stages and JUNAC Moderate Drying Program Tabela 3: Variáveis climáticas das etapas de secagem artificial e programa de secagem moderada do JUNAC

\begin{tabular}{c|c|c|c|c|c}
\hline $\begin{array}{c}\text { Stages of the Drying } \\
\text { Process }\end{array}$ & $\begin{array}{c}\text { Moisture } \\
\text { Content }(\%)\end{array}$ & $\begin{array}{c}\text { Dry Bulb } \\
\text { Temperature }\left({ }^{\circ} \mathrm{C}\right)\end{array}$ & $\begin{array}{c}\text { Relative } \\
\text { Humidity }(\%)\end{array}$ & $\begin{array}{c}\text { Equilibrium } \\
\text { Humidity }(\%)\end{array}$ & $\begin{array}{c}\text { Drying Time or } \\
\text { Power }(*)\end{array}$ \\
\hline \multirow{2}{*}{ Initial Conditioning } & & 50 & 91 & 19 & 24 hours \\
\hline & Green - 51 & 50 & 87 & 17.5 & Variable \\
\hline & $50-41$ & 55 & 85 & 16 & - \\
Drying itself & $40-31$ & 60 & 62 & 13 & 3,5 \\
& $30-26$ & 65 & 51 & 70 & 3.5 \\
& $25-21$ & 70 & 45 & 6 & 3.0 \\
\hline Equalization & $20-10$ & 70 & 35 & 5 & 3.0 \\
\hline Final Conditioning & & 70 & 35 & 5 & Variable \\
\hline
\end{tabular}

(*) Drying power was calculated based on the average of the humidity range of the drying level and the equilibrium humidity.

\section{Drying Assessment}

Initial moisture, final moisture, time and drying rate were analyzed based on the recommendations of (JUNAC, 1989) and (DENIG, 2000). The drying rate was calculated using the following equations: (DENIG, 2000).

$$
\mathrm{Ts} 1=\frac{\% \mathrm{CHI}-30 \%}{\mathbf{T}_{1}} ; \mathrm{Ts} 2=\frac{30 \%-10 \%}{\mathrm{~T}_{2}}
$$

Where: Ts1, Ts2 = Free and Bound Water Drying Rates (\%CH h-1); \%CHI = Initial Moisture Content (\%); 30\% $=$ PSF $; 10 \%=$ Final Moisture Content; $\mathrm{T}_{1}, \mathrm{~T}_{2},=$ Drying Time between Moisture Ranges (hours).

The wood defects were evaluated at the end of the two drying methods used, of both the four loads of wood with and of the four loads of wood without air-drying pretreatment, considering the Peruvian Technical Standard: NTP 251.102 (2016) Sawn wood. Defects. Definition and classification.

\section{Statistical Analysis}

A completely randomized block design with $2 \times 2$ factorial arrangement was used for the development of the eight artificial drying trials of teak wood with two initial moisture levels (Green wood [H1] and PSF [H2]); two air circulation speeds (2.5 [V1]; $3.5 \mathrm{~m} \mathrm{~s}-1$ [V2]) and two levels of log location Base [B]; Topo [T]). Descriptive statistics were used to evaluate the dispersion of the observations. The normal distribution and homoscedasticity of the information were corroborated, analyzing the reaction of the wood using non-parametric and parametric tests at the $95 \%$ probability level (SALAS, 2018).

\section{RESULTS}

\section{Air Drying}

Table 4 shows that the drying time of load 3 was of $65 \%, 32.9 \%$, and $33.1 \%$ of that of loads 5,7 , and 8 respectively. ANOVA of the drying rates $(\mathrm{p}=0.00)$ showed significant differences, as it was significantly higher in load 3 (Fisher's Test). The Tukey test and ANOVA of the initial moisture content $(\mathrm{p}=0.904)$ and the final moisture content $(\mathrm{p}=0.996)$ of the wood loads showed no significant differences at a $95 \%$ confidence level. There were no structural drying defects at the ends, on the faces of the boards, and no warping. The evaluation was based on NTP 251.102 (2016). 
Table 4: Time and Free Water Drying Rate of Tectona grandis Wood in Air Drying.

Tabela 4: Tempo e taxa de secagem com água livre de madeira Tectona grandis em secagem ao ar.

\begin{tabular}{c|cc|ccc|c}
\hline \multirow{2}{*}{$\begin{array}{c}\text { Wood } \\
\text { Loading }\end{array}$} & \multicolumn{2}{|c|}{ Drying Time } & \multicolumn{3}{|c|}{ Moisture Content $(\%)$} & \multirow{2}{*}{$\begin{array}{c}\text { Drying Rate }(\% \\
\text { humidity/day) }(* *)\end{array}$} \\
\cline { 2 - 5 } & Hours & Days & Initial (*) & Final (*) & Extracted & hus (a) \\
$(3)$ & 371 & 15,5 & $93,4(\mathrm{a})$ & $35,2(\mathrm{a})$ & 58,2 & $2,6(\mathrm{~b})$ \\
$(5)$ & 572 & 23,8 & $97,1(\mathrm{a})$ & $35,8(\mathrm{a})$ & 61,3 & $1,4(\mathrm{c})$ \\
$(7)$ & 1130 & 47,1 & $95,0(\mathrm{a})$ & $35,5(\mathrm{a})$ & 59,5 & $1,2(\mathrm{c})$ \\
\hline
\end{tabular}

Equal letters do not present significant differences with the Tukey $(*)$ and Fisher's test $(* *)$.

Artificial Drying: Initial and Final Moisture Content of Wood Loads

In Table 5 the coefficients of variation $\leq 30 \%$ of the initial moisture content of the wood loads, indicated that they come from a Homogeneous Population (SALAS, 2018). ANOVA found a $(\mathrm{p}=0.464)$ in the wood loads with initial humidity $(\mathrm{H} 1)$, and $\mathrm{a}(\mathrm{p}=0.992)$ in the loads with $(\mathrm{H} 2)$, confirming with the Tukey test the non-existence of significant differences. Likewise, with the T-Student test, no significant differences were found $(\mathrm{p}=0.065)$ between the average final moisture content of $8.3 \%$ (40 samples) and the average final moisture content of $9 \%$ (40 samples by the kiln method) of eight wood loads, at a confidence level of $95 \%$.

Table 5: Variation Coefficient and ANOVA of the Initial and Final Humidity of eight Wood Loads Tabela 5: Coeficiente de variação e ANOVA da umidade inicial e final de oito cargas de madeira

\begin{tabular}{|c|c|c|c|c|c|c|}
\hline \multirow{2}{*}{$\begin{array}{c}\text { Initial } \\
\text { Humidity }\end{array}$} & \multicolumn{2}{|c|}{ Wood Loading } & \multirow{2}{*}{$\begin{array}{l}\text { Initial Humidity } \\
\text { Average }(\%)(* *)\end{array}$} & \multirow{2}{*}{$\begin{array}{c}\text { Variation } \\
\text { Coefficient }\end{array}$} & \multicolumn{2}{|c|}{ Average Final Moisture (\%) } \\
\hline & (\#) & (*) Code & & & Control Samples & Random Sample \\
\hline \multirow{5}{*}{$\begin{array}{l}\text { Green Wood } \\
\text { Moisture } \\
(\mathrm{H} 1)\end{array}$} & 1 & B-V1H1 & $95.06(\mathbf{a})$ & 18.98 & 7.9 & 7.5 \\
\hline & 2 & $\mathrm{~T}-\mathrm{V} 2 \mathrm{H} 1$ & 96.92 (a) & 20.82 & 8.0 & 10.7 \\
\hline & 4 & B-V2H1 & 102.98 (a) & 10.99 & 8.7 & 9.5 \\
\hline & 6 & $\mathrm{~T}-\mathrm{V} 1 \mathrm{H} 1$ & 86.64 (a) & 14.31 & 8.4 & 7.7 \\
\hline & \multicolumn{2}{|c|}{ Total Average } & 95.40 & - & 8.3 & 8.9 \\
\hline \multirow{5}{*}{$\begin{array}{l}\text { Humidity at PSF } \\
\qquad(\mathrm{H} 2)\end{array}$} & 3 & $\mathrm{~T}-\mathrm{V} 1 \mathrm{H} 2$ & 36.48 (a) & 30.02 & 7.0 & 8.5 \\
\hline & 5 & $\mathrm{~B}-\mathrm{V} 2 \mathrm{H} 2$ & 35.80 (a) & 14.34 & 7.3 & 10.1 \\
\hline & 7 & $\mathrm{~T}-\mathrm{V} 2 \mathrm{H} 2$ & 35.10 (a) & 17.74 & 9.5 & 9.2 \\
\hline & 8 & $\mathrm{~B}-\mathrm{V} 1 \mathrm{H} 2$ & 35.88 (a) & 6.59 & 9.3 & 8.4 \\
\hline & \multicolumn{2}{|c|}{ Total Average } & 35.82 & - & 8.3 & 9.1 \\
\hline \multicolumn{3}{|c|}{ General Average $(* * *)$} & - & - & 8.3 (a) & 9.0 (a) \\
\hline
\end{tabular}

(*) B: Tree Base; T: Tree Top; V1: $2.5 \mathrm{~ms}^{-\mathbf{1}}$; V2: $3.5 \mathrm{~ms}^{-\mathbf{1}}$; H1: Green Moisture; H2: Moisture in the PSF

(**) Means with the same letters indicate non-significant differences using the Tukey test and (***) T-student

Artificial Drying: Drying Time and Rate

The normal distribution of the total time of the wood drying process was verified ( $\mathrm{p}$-value $=0.564)$, and homoscedasticity $(p-v a l u e=0.152)$, with a confidence level of 95\%. ANOVA with a $(p=2.587 \mathrm{e}-07),(\mathrm{p}=0.003)$ and $(\mathrm{p}=0.022)$ of drying time by effect of initial humidity (H1) and (H2), air velocity (V1) and (V2) and the interaction of both respectively, indicated that the drying time of wood with initial humidity (H1) was significantly higher than that of initial humidity (H2) with velocities (V1) and (V2). Likewise, the drying time of wood with initial moisture (H1), was significantly longer with air velocity (V1) than with (V2), while with initial moisture of (H2) showed no significant differences as shown in Table 6. The effect of the position on stem height of (B) and (T) wood with a $(\mathrm{p}=0.052)$ did not induce significant differences at a confidence level of $95 \%$.

Table 6: Tukey's Test of Drying Time averages by interaction of Initial Humidity and Wind Velocity Tabela 6: Teste de Tukey do tempo de secagem pela interação da umidade inicial e velocidade do vento

\begin{tabular}{|c|c|c|c|c|c|c|}
\hline $\begin{array}{l}\text { Initial Humidity }(\%) \\
(*)\end{array}$ & $\begin{array}{l}\text { Air Velocity } \\
\left(\mathrm{m} \mathrm{s}^{-1}\right)(*)\end{array}$ & $\begin{array}{l}\text { Average Drying } \\
\text { Time }(\mathrm{h})(* *)\end{array}$ & $\begin{array}{l}\text { Degrees of } \\
\text { Freedom }\end{array}$ & $\begin{array}{c}\text { Lower } \\
\text { Limit }\end{array}$ & $\begin{array}{l}\text { Upper } \\
\text { Limit }\end{array}$ & $\begin{array}{c}\text { Tukey } \\
\text { Test }(* *)\end{array}$ \\
\hline حPSF (H2) & $3.5(\mathrm{~V} 2)$ & 89,7 & 35 & 68,7 & 111 & c \\
\hline$\sim \mathrm{PSF}(\mathrm{H} 2)$ & $2.5(\mathrm{~V} 1)$ & 95,4 & 35 & 74,4 & 116 & bc \\
\hline Green wood (H1) & $3.5(\mathrm{~V} 2)$ & 121,4 & 35 & 100,4 & 142 & b \\
\hline Green wood (H1) & $2.5(\mathrm{~V} 1)$ & 165,5 & 35 & 144,5 & 187 & $\mathbf{a}$ \\
\hline
\end{tabular}

(*) H1: Green Humidity; H2: Humidity in the PSF; V1: $2.5 \mathrm{~ms}^{-1}$; V2: $3.5 \mathrm{~ms}^{-1}$

(**) Means with the same letters indicate non-significant differences using the Tukey test 
Normal distribution of the drying rate of wood loads ( $p$-value=0.273) and homoscedasticity (pvalue $=0.077)$ were established. ANOVA $(p=3.96 \mathrm{e}-07)$ and the T-Student test showed that the drying rate of free water by air velocity effect (V2) was significantly higher than that of (V1). While the drying rate of hygroscopic water by air velocity effect (V2) was not significantly higher than that of (V1). ANOVA ( $p=2.2$ e-016) and the Tukey test also showed that the drying rate of free water was significantly higher than that of hygroscopic water (Table 7). The effect of position on the stem height of $(B)$ and $(T)$ wood $(p=0.152)$ did not induce significant differences at a level of confidence of $95 \%$.

Table 7: Hygroscopic and Free Water Drying Rate and Tukey Test due to the effect of the air velocity Tabela 7: Taxa de secagem de água livre e higroscópica e teste de Tukey devido ao efeito da velocidade do ar

\begin{tabular}{|c|c|c|c|}
\hline \multirow{2}{*}{ Humidity Range (\%) } & \multicolumn{2}{|c|}{ Wood Loading } & Drying Rate \\
\hline & $\mathrm{N}^{\circ}$ & Code $(*)$ & $\left(\% \mathrm{CH}\right.$ hour $\left.^{-1}\right)(* *)$ \\
\hline \multirow{3}{*}{$\begin{array}{l}\text { Green }(\mathrm{H} 1) \text { to the PSF }(\mathrm{H} 2) \\
\text { (Free Water) }\end{array}$} & $2 \mathrm{y} 4$ & $\mathrm{~T}$ y $\mathrm{B}-\mathrm{V} 2$ & $1.32(\mathrm{a})$ \\
\hline & $1 \mathrm{y} 6$ & T y B -V1 & $0.85(\mathrm{~b})$ \\
\hline & \multicolumn{2}{|c|}{ Average $(* * *)$} & $1.08(\mathrm{a})$ \\
\hline \multirow{4}{*}{$\begin{array}{l}\text { PSF (H2) to the } 10 \% \\
\text { (Hygroscopic Water) }\end{array}$} & $2,4,5,7$ & T y B -V2 & $0.28(\mathrm{a})$ \\
\hline & $1,3,6,8$ & T y B -V1 & $0.25(\mathrm{a})$ \\
\hline & \multicolumn{2}{|c|}{ Average $(* * *)$} & $0.26(b)$ \\
\hline & \multicolumn{2}{|c|}{ General Average } & 0.67 \\
\hline
\end{tabular}

(*) B: Base; T: Top; V1: $2.5 \mathrm{~m} \mathrm{~s}^{-1}$; V2: $3.5 \mathrm{~m} \mathrm{~s}^{-1}$; H1: Start of drying in green moisture; H2: Start of drying in humidity at PSF (**) Equal letters indicate non-significant differences by the Tukey and (***) T-student tests.

\section{Artificial Drying: Drying Defects}

All of the 480 boards that made up the eight loads of the study were evaluated according to the Peruvian Technical Standard (NTP) 251.102 (2016). No collapse defects or cracks were observed at the ends and the faces of the boards. However, warping defects were observed, whose percentage presence are shown in Table 8 . The average percentage of warping types in the eight wood loads were: grooved (28.6\%), warped (11.9\%) and curved $(1 \%)$. ANOVA of the percentages of wood with and without warping and rejected and accepted for the effect of air velocity ( $\mathrm{p}=0.92 ; \mathrm{p}=0.89)$; initial moisture level $(\mathrm{p}=0.345 ; \mathrm{p}=0.098)$; and wood position in tree height ( $\mathrm{p}=0.92$; $\mathrm{p}=0.197$ ) showed no significant differences at $95 \%$ confidence level.

Table 8: Drying defects in the artificial drying of eight loads of teak wood with the study variables Tabela 8: Defeitos na secagem artificial de oito cargas de madeira de teca com as variáveis de estudo

\begin{tabular}{cccccc}
\hline \multirow{2}{*}{ Study Variables } & \multicolumn{4}{c}{ Wood according to Standard (\%) (*) } \\
\cline { 2 - 5 } & & with Warping & without Warping & Rejected & Accepted \\
\hline \multirow{2}{*}{$\begin{array}{c}\text { Air Velocity } \\
\left(\mathrm{m} \mathrm{s}^{-1}\right)\end{array}$} & 2,5 & $60,8(\mathrm{a})$ & 39,2 & $3,3(\mathrm{a})$ & 96,7 \\
\cline { 2 - 6 } & 3,5 & $61,7(\mathrm{a})$ & 38,3 & $3,8(\mathrm{a})$ & 96,2 \\
\hline \multirow{2}{*}{$\begin{array}{c}\text { Initial } \\
\text { Humidity }\end{array}$} & Green & $57,5(\mathrm{a})$ & 42,5 & $5,8(\mathrm{a})$ & 94,2 \\
\hline \multirow{2}{*}{$\begin{array}{c}\text { Position in the } \\
\text { Tree }\end{array}$} & PSF & $65,0(\mathrm{a})$ & 35,0 & 1,3 (a) & 98,7 \\
\cline { 2 - 6 } & Base & $60,8(\mathrm{a})$ & 39,2 & $5,4(\mathrm{a})$ & 94,6 \\
\hline
\end{tabular}

(*) By study variable, equal letters indicate non-significant differences between averages.

\section{DISCUSSION}

\section{Air Drying}

The air drying times of loads 3 (top) and 5 (base) were carried out in the autumn period, while those of loads 7 (top) and 8 (base), where carried out between autumn and winter (Table 2); the autumn period yielded higher temperature and air velocity values, as well as increased drying based on greater evaporation of water from the wood, while higher relative humidity and precipitation values in winter led to a decrease in wood drying (DENIG et al., 2000). In this regard, Pearson's correlation explains the results showing that free water drying rate showed a positive linear relationship with the temperature (0.997) and the air velocity (0.987), and a negative 
linear relationship with the drying time (-0.976), the relative humidity (-0.996) and the precipitation (-0.97), which is congruent with the observations of several authors on air drying (JUNAC, 1989; Simpson, 1991; mdt, 1991); SIMPSON, 1991; MDT, 2007). Therefore, regardless of the position of the wood in the tree (base or top) (BONDUELLE et al., 2015), loads 3 and 5 reached the average final moisture content of $36 \%$ in a shorter time compared to loads 7 and 8. The importance of air drying aims to remove free water by around $25 \%$ to $30 \%$ to reduce the kiln-drying time (DENIG et al., 2000; LIEBL et al., 2017).

Table 4 shows the free water drying rate of the four wood loads in air drying. It can be observed that load 3 dried with an initial moisture content of $93.1 \%$ in the least number of days (15.5 days), with the highest average drying rate (3.8\% moisture per day) in relation to the other loads, in agreement with the results of Braz et al. (2015). When air-drying teak of lower initial moisture content (70.1\%) and age (17 years), a moisture content of $31.6 \%$ was obtained in 12 days, with a drying rate of $3.1 \%$ of moisture per day. Unlike what was found by Zen et al. (2019) when air-drying 15-year-old Eucalyptus spp., obtaining a lower drying rate from green to $30 \%$ (1.5\% moisture per day), as the factors that influence the drying process, apart from climatic variables, are species, board thickness and initial moisture (LOIOLA et al., 2015; DENIG et al., 2000).

ANOVA of the differences between the initial moisture values and those of the final moisture content of the four wood loads were not significant at a 95\% confidence level. Therefore, their differences did not significantly influence (SALAS, 2018) the duration of the air-drying time of the four wood loads, being the climatic variables the determining factors (ZEN et al., 2019).

The wood did not present structure drying defects at the ends of the boards, as they were sealed with liquid wax. Likewise, none of the boards presented cracks on the faces. Neither were warping defects observed that could affect the correct stacking for conventional drying treatment, due to its medium density $\left(0.56 \mathrm{~g} \mathrm{~cm}^{-3}\right)$, low volumetric shrinkage (8.54\%), and straight grain (MIRANDA et al., 2011; BOUNDUELLE et al., 2015; BERROCAL et al., 2017), and the correct stacking of the wood (JUNAC, 1989).

Artificial Drying - Initial \& final moisture content of wood loads

The non-existence of significant differences between the values of initial moisture content of green wood (H1), wood in the PSF (H2) (Tukey) and final moisture content (T-student), indicated their non-significant influence (SALAS, 2018) on the differences observed in the drying time and rate due to the effect of the studied variables. According to Quintanar (2018), the final moisture content of wood is one of the most important parameters to be considered for the different purposes in which it will be used. As the product is wood with a given final moisture content, the quality of the process is measured by the uniformity of the final moisture content achieved at $10 \%$. The average initial moisture content (H1) was of $95.4 \%$, in agreement with other studies performed with teak wood, Berrocal et al. (2017), with 11-year-old wood from Costa Rica, from $85 \%$ to $115 \%$. Loiola et al. (2015), with wood from homogeneous populations located in the state of Paraná in Brazil, determined $115 \%$. Betancur et al. (2000) with 9-year-old wood from Puerto Libertador in Colombia found from $93 \%$ to $00 \%$. In turn, Braz et al. (2015), with wood from 15-year-old experimental plantations in Vale do Rio Doce, determined an average initial moisture content of $71 \%$.

Drying rate $\&$ time of the artificial drying process

The Tukey tests shown in Table 6 indicate that the drying time of wood with saturated initial moisture (H1) was significantly longer than the drying time of wood with initial moisture in the PSF (H2), because of the greater amount of free water in wood with moisture condition (H1) as opposed to wood with moisture condition (H2), the free water of which was extracted by air drying (DENIG et al., 2000; LIEBL et al., 2017). It is also observed that the drying time of wood with initial moisture (H1), was significantly longer with lower air velocity (V1), as it induced less evaporation of free water than (V2), which provides more energy per unit time (AQUINO et al., 2010). The drying time of wood with initial humidity of (H2) did not show statistical differences with the air velocity (V1) and (V2), because the heat transfer by convection starts to be insignificant, due to the fact that the heat transfer by conduction starts to occur prominently, as the flow of hygroscopic water depends on the diffusion phenomenon (STEINER et al. (2011).

When comparing teak drying investigations with an air velocity of $2.5 \mathrm{~m} \mathrm{~s}^{-1}$, the 33 -year-old wood of this study required on average 165.5 hours to dry from a $95 \%$ to $10 \%$ final moisture content, which is longer than the amount of time obtained by Berrocal et al. (2017) with 11-year-old wood from Costa Rica when drying from 101\% to $12.4 \%$ in 88 hours. In turn, Betancur et al. (2000) dried 9-year-old wood from Puerto Libertador, Colombia, from $110 \%$ to $12 \%$ in 110 hours. We consider that with age the proportion of heartwood and the percentage of extractives (MIRANDA et al., 2011; MOYA et al., 2014) increase, decreasing heartwood permeability and water displacement in wood (AHMEND; CHUN, 2011; BERROCAL et al., 2017).

The Tukey and T-Student test shown in Table 7 indicate that the drying rate of free water with initial moisture (H1) was significantly higher than that of bound water with initial moisture (H2), showing a greater increase in drying rate with air velocity (V2) than with (V1), while the drying rate of bound water with initial 
moisture of (H2), showed no statistical difference between air velocity (V2) and (V1) (STEINER et al., 2011; MAJKA, 2012). In this regard, Berberovic and Milota (2011) when drying western hemlock (Tsuga heterophylla) wood found that initial moisture content is positively correlated with drying speed, while the basic density and heartwood percentage are negatively correlated. The impact of initial moisture on drying speed varies as the board dries to lower moisture content. Likewise, Santini and Haselein (2002), when analyzing the effect of air velocity on drying rate in Pinus elliottii wood, found a directly proportional relationship between drying rate, air velocity, and wood moisture content. The influence of air velocity on the drying rate decreased as wood moisture decreased. In this regard, Loiola et al. (2015), when drying 20-year-old teak wood in a solar kiln, observed an average drying rate of free water that was $0.95 \%$ day $^{-1}$ higher than that of hygroscopic water, which was of $0.51 \%$ day $^{-1}$.

In this study, an overall average drying rate of $0.67 \% \mathrm{CH} \mathrm{h}^{-1}$ was achieved with 33-year-old teak wood, which was lower than the rate found by Betancur et al (2000) with 9-year-old teak wood using mild, moderate and strong drying programs, registering average drying rates of $0.68,0.72$, and $0.96 \% \mathrm{CH}$ h- 1 respectively. In turn, Berrocal et al. (2017), when drying 11-year-old teak wood, obtained average drying rates of 1.2 to $2.1 \% \mathrm{CH} \mathrm{h}^{-1}$. In this regard, several authors confirm the effect of age on the higher density value, the proportion of heartwood, the content of extractives and its negative influence on the drying rate and the longer duration of the process. Thus, Cremonez et al. (2015) confirm the increase of density in teak wood with age, while Moya et al. (2014), when assessing the properties of teak heartwood, determined that a higher heartwood content is present at an advanced age, being the main characteristic related to the accumulation of extractives. This, according to Ahmed and Chun (2011), favors the formation of tyloses that decrease the permeability of the wood for water displacement in the drying process. Conners (2012) mentions that free water does not affect wood properties as bound water does, but its removal decreases thermal conductivity and permeability decreasing the drying rate. In that sense, Denig et al. (2000) point out that PSF refers to individual cells instead of pieces of wood, and by drying the wood from the outside in, the outside will have a lower moisture content than the inside, in these conditions only some cells will be exactly in the PSF, keeping the free water in the cell cavities and the bound water in the cell walls in a continuous moisture gradient between the outside and inside of the wood, requiring the bound water gradually more energy decreasing the drying rate.

Artificial drying: Drying defects

ANOVA and Tukey test of the percentage of wood with and without warping, as well as rejected and accepted wood, according to the standard presented in Table 8, show that the differences in the percentage of warping observed with the use of air velocities (V1) and (V2) were not significant. This is because the drying quality depends mainly on the quality of the wood, and the air velocity influences the formation of cracks in the wood faces when the drying program is inadequate for the species (DENIG et al., 2000). In this regard, Wallace and Avramidis (2016) state that little work has been done to study the way in which air velocities affect the quality of the final product in terms of moisture distribution, shrinkage, as well as drying defects. ANOVA and Tukey test of the effect of the two initial moisture levels (H1) and (H2) on the development of warping in lumber showed no significant differences. Given that the importance of wood with high moisture content is referred to the longer drying time and the susceptibility to collapse due to the application of a highly severe drying program (very high drying gradient) to very wet wood (DENIG et al., 2000; SANTINI; HASELEIN, 2002). In this study, to control the development of collapse and cracks on the teak wood faces, the experience of Betancurt et al. (2000) with 9year-old wood was taken into account, performing a gradual decrease of the \% RH of air, to control the decrease of the \% $\mathrm{CH}$ equilibrium (increase of the drying gradient), avoiding the development of the wood collapse, and to control the increase of the drying efforts avoiding the formation of cracks on the wood faces ( JUNAC, 1989; Denig et al., 2000; Conners; 2012), achieved with the two phases of initial conditioning shown in Table 3.

Likewise, ANOVA and Tukey test of the effect of the two levels of wood position in tree height (B) and (T) on the development of wood warps showed no significant differences. The basic density of teak wood tends to decrease with the height of the shaft, but from the middle height the tree tends to increase its value without reaching that of the wood near the base of the tree (BOUNDUELLE et al., 2015). The density (or specific gravity) of teak $\left(0.56 \mathrm{~g} \mathrm{~cm}^{-3}\right)$ is a good predictor of wood drying quality, straight grain and a T/R of 2.5 , significantly reduces the presence of drying defects (MIRANDA et al., 2011; MOYA et al., 2014). The cracking of the ends of the wood was controlled by sealing the ends with liquid wax, as well as compact stacking without gaps between boards to avoid the flow of air towards the ends of the stack, and the use of air routers to favor the velocity and uniformity of the air in the boards that compose it (JUNAC, 1989). Bedelean (2015), in a comparative analysis based on different options for the installation of baffles in the drying chamber, measured the air velocity at different points located on the exit face of the wood stack. The results showed that the position of the baffles inside the drying kiln played an important role in the average air velocity and its uniformity inside the woodpile. According to Bonduelle et al. (2015), when analyzing the variations of the physical properties of 18-year-old teak wood from the 
municipality of Brasnorte in the state of Mato Grosso, Brazil, no large variations in axial direction were observed, which affirms there is no need to differentiate the wood.

In relation to the 1.0-m wide study wood pile, Liebl et al. (2017), when evaluating its influence on the drying speed, final moisture uniformity and defects in the air drying of Eucalyptus spp. observed that the width of $0.9 \mathrm{~m}$ as opposed to $1.8 \mathrm{~m}$, caused an increase in both the speed and the quality of the drying, relating to a lower final moisture value and moisture range between boards, as well as lower drying defects.

\section{CONCLUSIONS}

- The drying time of the wood showed a significant direct relationship with the initial moisture content, and an inverse relationship with the air velocity.

- The drying rate of free water showed a significant direct relationship with air velocity, and was significantly higher than that of hygroscopic water.

- The position of the wood in the height of the stem did not significantly influence the time, rate and quality of air and artificial drying of teak wood.

- The drying quality of teak wood showed no significant dependence on air velocity, wood position in stem height, and initial drying moisture.

\section{REFERENCES}

AHMED, S. A.; CHUN, S. K. Permeability of Tectona grandis L. as affected by wood structure. Wood Science and Technology, Munich, Germany, v. 45, p. 487-500, 2011.

AQUINO, G. V. L.; RODRIGUEZ, R. J.; MENDEZ, L. L.; SANDOVAL, T. S. Evaluación de programas de secado para madera de chalamite (Pinus pseudostrobus). Madera y Bosques, Xalapa, Mexico, v. 16, n. 2, p. 3546, 2010.

BEDELEAN, B. Influence of various options to baffles setup on air velocity and its uniformity in a drying kiln. Pro Ligno. Brasov, Rumania, v. 11, n. 4, p. 355-359, 2015.

BERBEROVIC, A.; MILOTA, M. Impact of Wood Variability on the Drying Rate at Different Moisture Content Levels. Forest Products Journal, Kuala Lumpur, Malaysia, v. 61, n. 6, p. 435 - 432, 2011.

BERROCAL, A.; MOYA, R.; RODRIGUEZ, S. M.; MUÑOZ, F. Drying of plantation-grown Tectona grandis wood with daily-controlled drying rate schedules. Journal of Tropical Forest Science, Selangor, Malaysia, v. 29, n. 1, p. 69-79, 2017.

BETANCUR, S. C.; HERRERA, J.; MEJIA, L.C. Estudio de las propiedades físicas y mecánicas, trabajabilidad y secado de la teca (Tectona grandis L.f.). Puerto Libertador (Córdoba). Facultad Nacional de Agronomía Medellín, Medellín, Colombia, n v. 53, n. 1, p. 913-939, 2000.

BONDUELLE, M. G.; IWAKIRI, S.; TRIANOSKI, R.; PRATA, G. J.; ROCHA, Y. V. Analise da massa especifica e da retratibilidade da madeira de Tectona grandis nos sentidos axial e radial do tronco. Floresta, Curitiba, PR, v. 45 n. 4, p. $671-680,2015$.

BRAZ, L. R.; DUARTE, C. P.; OLIVEIRA, S. T.; MOTTA, P. J.; ROSADO, M. A. Curva Característica de Secagem da Madeira de Tectona grandis e Acacia mangium ao Ar Livre. Floresta e Ambiente, Rio de Janeiro, Brasil, v. 22, n. 1, p. 117-123, 2015.

CONNERS, T. Hardwood dry kiln operation. A manual for operators of small dry kilns. University of Kentucky, 2012, 114 p.

CREMONEZ, G. V.; ZEN, R. L.; KLITZKE, J. R.; ROCHA, P.M.; FRANÇA, C. M. Influence of the age on specific gravity and janka hardness in the wood of teak (Tectona grandis L.F.) for floor. Australian Journal of Basic and Applied Sciences, Perth, Australia, v. 9, n. 35, p. 300-305, 2015.

DENIG, J.; WENGERT, E. M.; SIMPSON, W. T. Drying hardwood lumber. Gen. Tech. Rep. FPL-GTR-118. Madison, WI: U.S. Department of Agriculture, Forest Service, Forest Products Laboratory. 2000, 138p.

JUNTA DEL ACUERDO DE CARTAGENA (JUNAC). Manual del Grupo Andino para el secado de maderas. Lima, Peru, 1989. 104 p. 
LIEBL, A. O.; LOIOLA, L. P.; ZEN, R. L.; KLITZKE, J. R.; ROCHA, P. M. Influência dos Parâmetros Dimensionais da Pilha na Qualidade da Madeira de Eucalyptus spp. Submetida à Secagem ao Ar. Floresta e Ambiente, Rio de Janeiro, Brasil, v. 24, e00105514, 2017.

LOIOLA, P. L.; JUIZO, F. C.; MARCHESAN, R.; KLITZKE, J. R.; ROCHA, P. M. Drying of wood from Mimosa scabrella, Eucalyptus dunnii and Tectona grandis insolar kiln, in Brasil. Australian Journal of Basic and Applied Sciences, Perth, Australia, v. 9, n. 5, p. 445-453, 2015.

MAJKA, J. The influence of fan speed reduction on airflow uniformity in timber stack during kiln drying. Wood Research, Karlova, Eslovaquia, v. 57, n. 3, p. 479-488. 2012.

MIRANDA, I.; SOUSA, V.; PEREIRA, H. Wood properties of teak (Tectona grandis) from a mature unmanaged stand in East Timor. Journal of wood Science, Tokio, Japan, v. 57, p. 171 - 178. 2011.

MOYA, R.; BOND, B.; QUESADA, H. A review of heartwood properties of Tectona grandis trees from fastgrowth plantations. Wood Science and Technology, Munich, Germany v. 48, p. 411-433, 2014.

NORMA TECNICA PERUANA (NTP) 251.102.2016. Madera y Carpintería para construcción. Madera aserrada. Defectos. Clasificación y métodos de medición, Peru, 2016.

QUINTANAR, O. J. Methodology for evaluation of quality control in artificial wood drying. Revista de Investigación y Desarrollo, Madrid, España, v. 4, n. 13, p. 8-13, 2018.

SALAS, A. Métodos estadísticos para la Investigación Científica, Editorial Grupo Compás, Guayaquil Ecuador, 2018. 161p.

SANTINI, E. J.; HASELEIN, C. R. Efeito da temperatura e velocidade do ar sobre a taxa de secagem da madeira de Pinus elliottii Engelm. Ciência Florestal, Santa María, Brasil, v. 12, n. 2, p. 99-106, 2002.

STEINER, Y.; VESTOL, I. G.; HORN, H.; MAGNAR, S. K. Optimizing the Air Velocity in an Industrial Wood Drying Process. Journal Wood Science \& Engineering, Abingdon, United Kingdom, v. n. 6, p. 21-33, 2011.

VIKBERG, T.; HÄGG, L.; ELUSTONDO, D. Influence of fan speed on airflow distribution in a batch kiln. Wood Material Science \& Engineering, London, United Kingdom, v. 10, n. 2, p. 197-204, 2015.

WALLACE, J.; AVRAMIDIS, S. Impact of airflow on hem-fir kiln drying. Drying Technology, London, United Kingdom, v. 34, n. 11, p. 1354-1358, 2016.

ZEN, R. L. et al. Secagem ao ar livre da madeira serrada de eucalipto. Journal of Biotechnology and Biodiversity, Federal University of Tocantins, v. 7, n. 2, p. 291-298, 2019. 